\title{
Peningkatan Kapasitas Masyarakat Dalam Bidang Layanan Wisata Di Kampung Bekelir, Kota Tangerang
}

\author{
Yustisia Kristiana ${ }^{1}$, Theodosia C. Nathalia ${ }^{2}$, Rosdiana Pakpahan ${ }^{3}$, Nonot Yuliantoro ${ }^{4}$, \\ Vasco A. H. Goeltom ${ }^{5}$ \\ ${ }^{12345}$ Universitas Pelita Harapan \\ yustisia.kristiana@uph.edu, theodosia.nathalia@uph.edu, rosdiana.pakpahan@uph.edu, \\ nonot.yuliantoro@uph.edu, vasco.goeltom@uph.edu
}

\begin{abstract}
Abstrak
Provinsi Banten menyimpan beragam potensi pariwisata. Salah satu wilayah dari Provinsi Banten yaitu Kota Tangerang ikut berupaya mengembangkan potensi pariwisata. Kota Tangerang yang berada dalam wilayah administratif Provinsi Banten dan secara regional mempunyai keterkaitan yang sangat erat dengan Ibu Kota Jakarta, saat ini berkembang menjadi kota yang mengandalkan dari sektor jasa, pariwisata, perdagangan dan permukiman. Kota Tangerang memiliki keragaman daya tarik wisata baik budaya, sejarah, buatan hingga wisata kreatif. Salah satu daya tarik wisata kreatif yang dikembangkan adalah Kampung Bekelir. Kampung Bekelir merupakan salah satu yang menjadi perhatian dari pemerintah dan sejak tahun 2017 telah diresmikan sebagai Kampung Wisata. Kampung Bekelir dikelola oleh masyarakat setempat dan seiiring dengan mulai dikenalnya tempat ini sebagai daya tarik wisata, maka dibentuklah Pokdarwis (Kelompok Sadar Wisata). Permasalahan yang dihadapi oleh kelompok ini adalah belum semua masyarakat berpartisipasi. Hal ini karena belum optimalnya kapasitas masyarakat khususnya dalam bidang layanan wisata. Peningkatan kapasitas masyarakat sangat diperlukan dalam mendukung Kampung Bekelir sebagai destinasi wisata kreatif dan kampung wisata yang berkelanjutan. Solusi yang ditawarkan adalah dengan memberikan penyuluhan, pelatihan serta pendampingan. Metode yang dilakukan yaitu sosialisasi program, melakukan penyuluhan maupun pelatihan dan evaluasi. Kegiatan yang dilakukan dapat dirasakan manfaatnya bagi mitra. Luaran dari kegiatan ini adalah terwujudnya pemahaman masyarakat tentang pengelolaan daya tarik wisata yang berkelanjutan, terwujudnya standar pengelolaan homestay dan terciptanya kreasi makanan dan minuman yang berbahan lokal.
\end{abstract}

Kata Kunci: daya tarik wisata kreatif, peningkatan kapasitas masyarakat, Kampung Bekelir

\section{PENDAHULUAN}

Salah satu provinsi di Indonesia yang menyimpan potensi pariwisata adalah Banten. Provinsi Banten terdiri dari empat kota dan empat kabupaten, yakni: Kota Tangerang, Kota Tangerang Selatan, Kota Cilegon, Kota Serang, Kabupaten Tangerang, Kabupaten Pandeglang, Kabupaten Lebak, dan Kabupaten Serang. Pengembangan pariwisata Provinsi Banten menurut Rencana Induk Pengembangan Pariwisata Daerah (RIPPDA) Pariwisata tahun 2015 diidentifikasikan atas 526 daya tarik wisata yang tersebar di seluruh wilayah Provinsi Banten.
Sebagai salah satu bagian dari Provinsi Banten, Kota Tangerang ikut berupaya mengembangkan potensi pariwisata melalui kebijakan publik yang ditujukan untuk itu. Dengan status otonom yang dimiliki, Pemerintah Kota Tangerang memiliki wewenang untuk mengembangkan potensi-potensi yang ada di Kota Tangerang, salah satu diantaranya ialah potensi pariwisata yang mendatangkan keuntungan bagi Kota Tangerang itu sendiri. Didukung dengan adanya akses dari Bandar Udara Internasional Soekarno-Hatta, sudah seharusnya melihat peluang ini untuk memajukan pengelolaan pariwisata. Kekayaan potensi wisata yang dimiliki oleh Kota

$$
\text { Ekonomi, Sosial, dan Budaya }
$$


Tangerang tentu saja memerlukan pengelolaan yang baik dan tepat. Untuk mengelola potensi tersebut, peran ada di tangan masyarakat dan pemerintah yang mengeluarkan kebijakan-kebijakan yang mendukung pengembangan potensi tersebut.

Kecamatan Tangerang merupakan sebuah kecamatan di Kota Tangerang, Provinsi Banten. Kecamatan Tangerang terletak di pusat kota Tangerang, tepatnya di titik $0 \mathrm{Km}$ Kota Tangerang. Kota Tangerang memiliki potensi dikembangkan untuk menjadi kota wisata budaya. Dengan adanya Undang-Undang No. 23 Tahun 2014 tentang Pemerintahan Daerah, Pemerintah Daerah diharuskan dapat mengembangkan sumber daya pariwisata dan ekonomi kreatif dengan melaksanakan peningkatan kapasitas sumber daya manusia pariwisata dan ekonomi kreatif tingkat dasar (Republik Indonesia, 2004).

Kota Tangerang yang berada dalam wilayah administratif Provinsi Banten dan secara regional mempunyai keterkaitan yang sangat erat dengan Ibu Kota Jakarta, saat ini berkembang menjadi kota yang mengandalkan dari sektor jasa, pariwisata, perdagangan dan permukiman. Kota Tangerang memiliki keragaman daya tarik wisata baik budaya, sejarah, buatan hingga wisata kreatif. Salah satu daya tarik wisata kreatif yang dikembangkan adalah Kampung Bekelir. Pariwisata kreatif adalah pariwisata yang diarahkan menuju pengalaman bagi wisatawan yang terlibat dan bersifat otentik, dengan pembelajaran partisipatif dalam seni, warisan, atau karakter khusus dari suatu tempat (Richards dan Raymod, 2000). Kampung Bekelir merupakan salah satu yang menjadi perhatian dari pemerintah dan sejak tahun 2017 telah diresmikan sebagai Kampung Wisata.

Keberadaan Kampung Bekelir sebagai daya tarik wisata kreatif mendorong wisatawan untuk berkunjung sehingga terdapat peningkatan jumlah kunjungan wisatawan. Kampung Bekelir dikelola oleh masyarakat setempat dan seiiring dengan mulai dikenalnya tempat ini sebagai daya tarik wisata, maka dibentuklah Pokdarwis (Kelompok Sadar Wisata). Namun permasalahan yag dihadapi oleh kelompok ini adalah kesiapan dari masyarakat dalam melayani wisatawan, belum semua masyarakat berpartisipasi. Hal ini karena belum optimalnya kapasitas masyarakat khususnya dalam bidang layanan wisata. Layanan wisata terkait dengan ketersediaan fasilitas baik yang berwujud maupun tidak berwujud yang dapat memberikan kepuasan bagi wisatawan.

Aktivitas wisata yang dapat dilakukan di Kampung Bekelir antara lain adalah mengelilingi kampung, berfoto di spot "instagramable", menikmati kuliner khas dan melakukan wisata edukasi menanam tanaman akuaponik. Untuk dapat melengkapi pengalaman berwisata maka perlu dilakukan pengembangan aktivitas wisata sehingga kepuasan wisatawan dapat tercapai, dan Kampung Bekelir dapat menjadi daya tark wisata yang berkelanjutan. Pengelolaan daya tarik wisata yang berkelanjutan masih menjadi hal baru bagi masyarakat sehingga perlu ditingkatkan. Bagi wisatawan yang hendak menginap telah dikembangkan akomodasi homestay, hanya saja belum memenuhi standar pengelolaan homestay sehingga perlu untuk distandarisasi.

Kreativitas dibutuhkan untuk meningkatkan daya saing kawasan wisata salah satunya adalah penyajian makanan maupun minuman lokal bagi wisatawan yang datang (Nathalia dan Kristiana, 2018). Saat ini wisatawan yang berkunjung ke Kampung Bekelir belum disuguhi makanan maupun minuman lokal. Kreativitas dalam pengolahan serta penyajian makanan dan minuman lokal akan semakin melengkapi pengalaman berwisata.

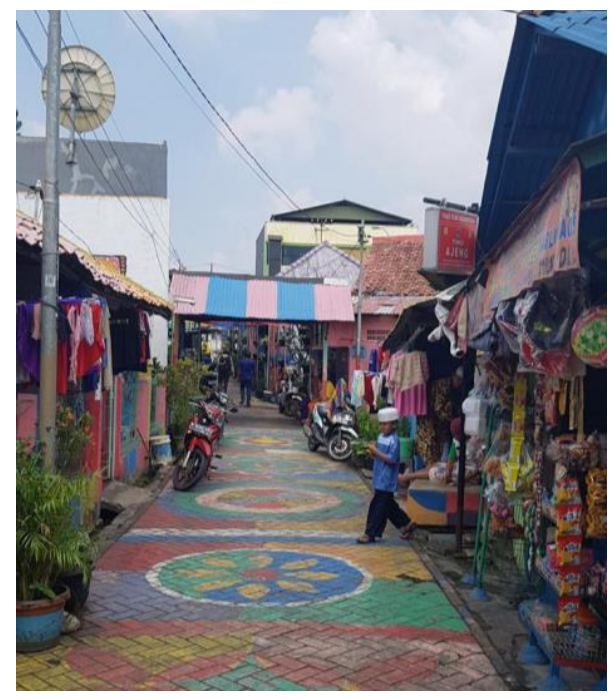

Sumber: Dokumentasi tim (2019)

Gambar 1. Suasana di Kampung Bekelir

Ekonomi, Sosial, dan Budaya 
Pengembangan pariwisata pada hakikatnya dapat dirasakan manfaatnya oleh masyarakat sebagai pelaku pariwisata sehingga peningkatan kapasitas masyarakat harus dilakukan secara optimal. Peningkatan kapasitas masyarakat sangat diperlukan dalam mendukung Kampung Bekelir sebagai destinasi wisata kreatif dan kampung wisata yang berkelanjutan.

Permasalahan prioritas yang dihadapi oleh mitra yaitu Pokdarwis Kampung Bekelir adalah (1) kurangnya pengetahuan masyarakat tentang pengelolaan daya tarik wisata yang berkelanjutan, (2) kurangnya pengetahuan masyarakat tentang pengelolaan homestay dan layanan prima. Masyarakat belum mengetahui standar dalam pengelolaan homestay dan layanan kepada wisatawan, dan (3) kurangnya pengetahuan dan keterampilan masyarakat tentang kreasi makanan dan minuman bagi wisatawan.

\section{METODE}

Tahap awal pelaksanaan adalah sosialisasi program. Tim akan melakukan pertemuan dengan Pemerintah Daerah yaitu Kelurahan Babakan dan mitra untuk berkoordinasi dalam mensosialisasikan program kegiatan.

Tahap kedua adalah mengadakan penyuluhan maupun pelatihan untuk meningkatkan kapasitas sumber daya manusia dalam pengelolaan Kampung Bekelir sebagai kampung wisata. Penyuluhan dan pelatihan dilaksanakan dengan topik terkait dengan daya tarik wisata, pengelolaan homestay dan kreasi makanan dan minuman.

Tahap terakhir merupakan tahap evaluasi. Tahap evaluasi, tahap ini merupakan tahap dimana program akan dievaluasi secara menyeluruh untuk meningkatkan mutu program dalam pengembangan program selanjutnya.

\section{HASIL DAN PEMBAHASAN}

\section{Pelaksanaan Kegiatan PkM}

Pelaksaanan kegiatan pengabdian kepada masyarakat bagi masyarakat Kampung Bekelir yang pertama diadakan pada hari Selasa, 2 Juli 2019. Dalam kegiatan ini peserta diberikan penyuluhan tentang daya tarik wisata, pelatihan tentang pengelolaan homestay dan kreasi minuman.

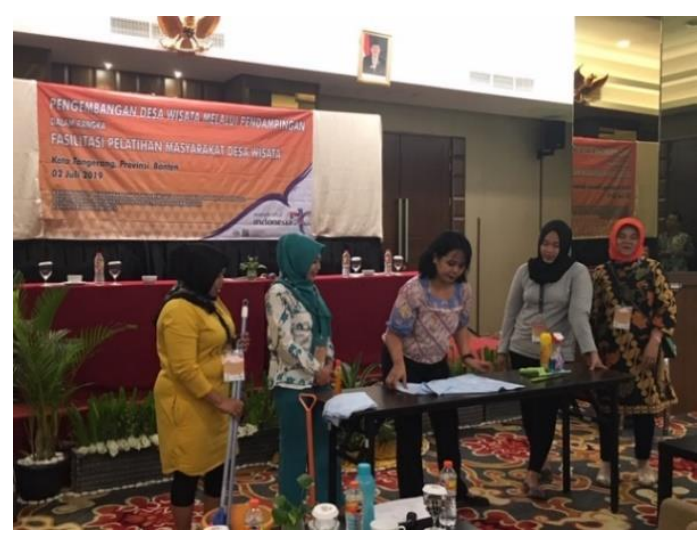

Sumber: Dokumentasi tim (2019)

\section{Gambar 2. Pelaksanaan PkM Pertama}

Kegiatan yang kedua diadakan pada hari Kamis, 3 Oktober 2019. Peserta kali ini diberikan pelatihan tentang kreasi makanan. Secara umum pada kedua kegiatan tersebut diawali dengan registrasi, kemudian penyampaian materi kepada peserta kegiatan, diikuti sesi demonstrasi dan tanya jawab.

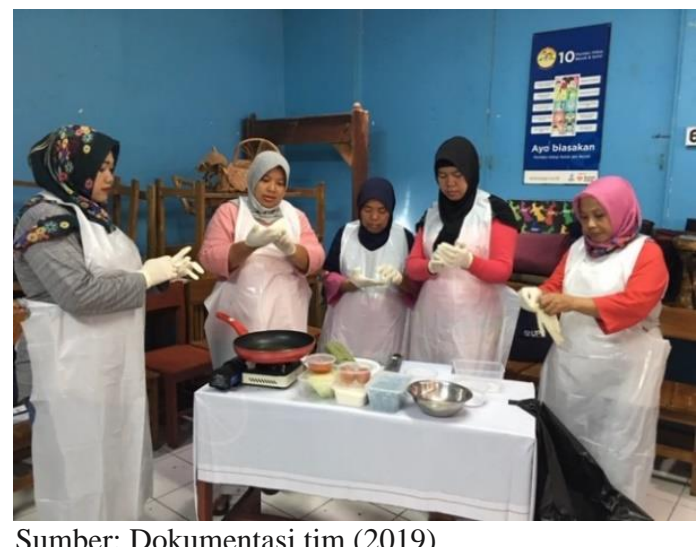

Sumber: Dokumentasi tim (2019)

Gambar 3. Pelaksanaan PkM Kedua berikut:

Susunan acara kegiatan adalah sebagai

Tabel 1. Susunan Acara

Ekonomi, Sosial, dan Budaya 


\begin{tabular}{|c|c|}
\hline \multicolumn{2}{|r|}{ Selasa, 2 Juli 2019} \\
\hline Waktu & Kegiatan \\
\hline $08.30-09.00$ & Registrasi \\
\hline $09.00-09.15$ & $\begin{array}{l}\text { Pembukaan oleh perwakilan dari } \\
\text { Asdep Pengembangan SDM } \\
\text { Pariwisata dan Hubungan } \\
\text { Antarlembaga Kementerian Pariwisata }\end{array}$ \\
\hline $09.15-10.00$ & $\begin{array}{l}\text { Sesi } 1 \\
\text { Penyuluhan Tentang Daya Tarik } \\
\text { Wisata yang Berkelanjutan: } \\
-\quad \text { Penyampaian materi } \\
-\quad \text { Diskusi } \\
\end{array}$ \\
\hline $10.00-12.00$ & $\begin{array}{l}\text { Sesi } 2 \\
\text { Pelatihan Tentang Pengelolaan } \\
\text { Homestay: } \\
\text { - Penyampaian materi } \\
\text { - Praktik }\end{array}$ \\
\hline $12.00-13.00$ & ISHOMA \\
\hline $13.00-15.00$ & $\begin{array}{l}\text { Sesi } 3 \\
\text { Pelatihan Kreasi Minuman: } \\
\text { - Penyampaian materi } \\
\text { - } \quad \text { Praktik }\end{array}$ \\
\hline $15.00-16.00$ & $\begin{array}{l}\text { Penutupan, penyerahan sertifikat dan } \\
\text { foto bersama }\end{array}$ \\
\hline Kamis, 3 Ol & ber 2019 \\
\hline Waktu & Kegiatan \\
\hline $08.30-09.00$ & Registrasi \\
\hline 09.00-09.15 & $\begin{array}{l}\text { Pembukaan oleh perwakilan dari } \\
\text { Kelurahan Babakan }\end{array}$ \\
\hline $09.15-11.15$ & $\begin{array}{l}\text { Pelatihan Tentang Kreasi Makanan: } \\
\text { - } \quad \text { Penyampaian materi } \\
\text { - Praktik }\end{array}$ \\
\hline $11.15-12.00$ & Penutupan dan foto bersama \\
\hline
\end{tabular}

\section{Hasil Kegiatan PkM}

Luaran yang dihasilkan dari kegiatan pengabdian kepada masyarakat yang pertama adalah terwujudnya pemahaman masyarakat tentang pengelolaan daya tarik wisata yang berkelanjutan. Hal ini dapat terlihat dari adanya partisipasi masyarakat dalam pengembangan Kampung Bekelir sebagai Kampung Wisata.

Luaran yang kedua adalah terwujudnya standar pengelolaan homestay. Kampung Bekelir mulai mengembangkan homestay yang memenuhi standar layanan. Hal mengacu kepada Asean Homestay Standard (2016) yang menyatakan bahwa sebuah homestay harus tersedia fasilitas dan perabotan dasar di kamar tidur tamu seperti kipas angin, meja tulis, lemari es mini, cermin, soket listrik, kelambu, dan lain-lain.

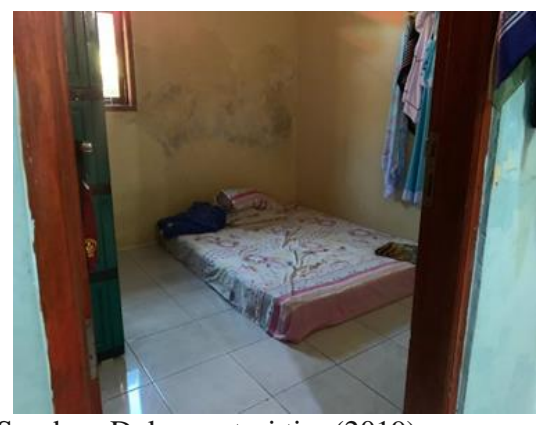

Sumber: Dokumentasi tim (2019)

Gambar 4. Kondisi Kamar Sebelum Kegiatan

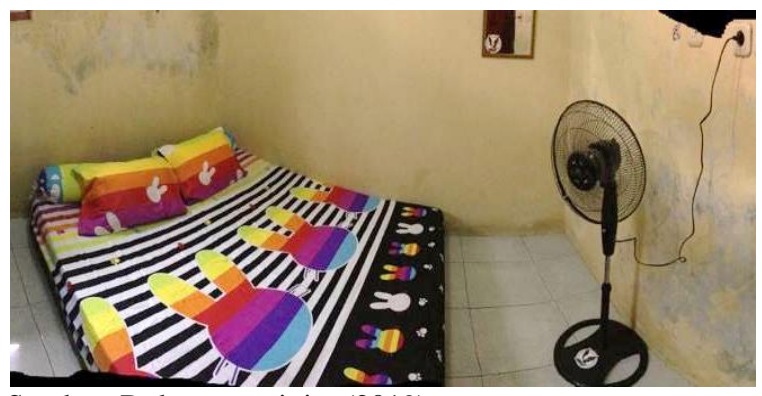

Sumber: Dokumentasi tim (2019)

Gambar 5. Kondisi Kamar Setelah Kegiatan

Luaran yang ketiga adalah terciptanya kreasi makanan dan minuman yang berbahan lokal. Untuk kreasi makanan yaitu burger tempe bekelir, nasi goreng bunga telang dan pisang goreng madu dengan saus santan. Kreasi minuman tradisional yang dikembangkan adalah es tambring, es bandrek kopi susu, es roco timun dan es asam somboy. Makanan dan minuman ini dapat menjadi referensi bagi masyarakat Kampung Bekelir dalam memberikan layanan makanan dan minuman bagi wisatawan yang datang. 


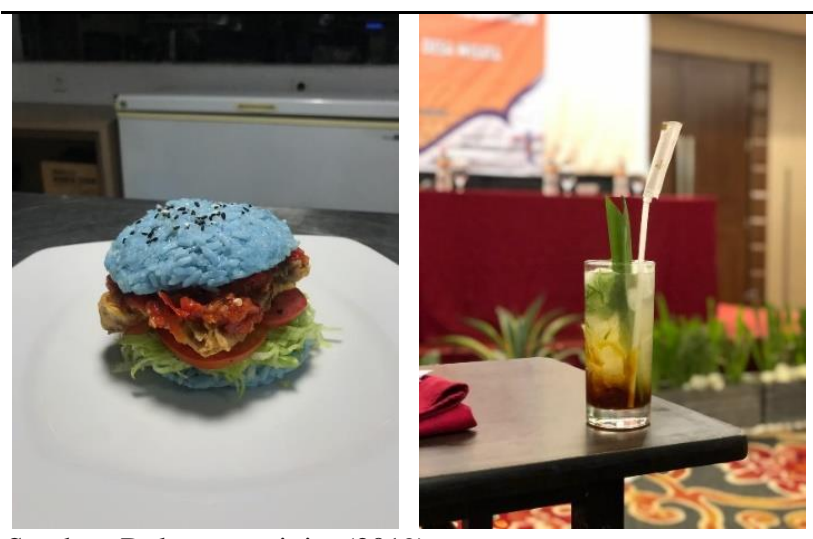

Sumber: Dokumentasi tim (2019)

Gambar 6. Kreasi Makanan dan Minuman

\section{SIMPULAN}

Kegiatan pengabdian kepada masyarakat pelatihan peningkatan kapasitas masyarakat dalam bidang layanan wisata dilakukan dengan tahapan yaitu sosialisasi program, pelaksanaan, dan evaluasi. Kegiatan dilaksanakan bagi masyarakat Kampung Bekelir, Kota Tangerang dan dilakukan dalam dua program. Kegiatan yang dilakukan dapat dirasakan manfaatnya bagi mitra. Luaran yang dihasilkan dapat membantu masyarakat Kampung Bekelir sebagai kampung wisata.

Saran yang diberikan untuk keberlanjutan pengabdian kepada masyarakat yaitu (1) mengadakan pelatihan lainnya untuk meningkatkan kapasitas masyarakat dalam bidang layanan wisata, dan (2) melakukan pendampingan dalam pengembangan Kampung Bekelir sebagai daya tarik wisata unggulan di Kota Tangerang. Untuk pelaksanaan pelatihan selanjutnya dapat disampaikan topik terkait layanan prima (service quality). Topik ini diperlukan bagi masyarakat untuk dapat memberikan kualitas layanan yang optimal bagi wisatawan yang berkunjung ke Kampung Bekelir. Direkomendasikan peserta pelatihan selanjutnya adalah kader muda untuk mengenalkan pariwisata sehingga potensi wisata di Kampung Bekelir dapat lebih dikembangkan.

\section{UCAPAN TERIMA KASIH}

Ucapan terima kasih disampaikan kepada LPPM Universitas Pelita Harapan, dan Dekan
Fakultas Pariwisata Universitas Pelita Harapan yang telah mendukung dalam pelaksanaan kegiatan. Terima kasih juga disampaikan kepada Lurah Babakan yang telah memberikan kesempatan untuk melaksanakan kegiatan, dan masyarakat Kampung Bekelir yang berpartisipasi dalam kegiatan.

\section{REFERENSI}

Asean (2016). Asean Homestay Standard. Jakarta: Asean Secretariat.

Nathalia, T. C., dan Kristiana, Y. (2018). Peningkatan Kreativitas Masyarakat Desa Gombengsari Sebagai Penunjang Daya Tarik Wisata di Kabupaten Banyuwangi. In Prosiding PKM-CSR Konferensi Nasional Pengabdian kepada Masyarakat dan Corporate Social Responsibility: Optimalisasi Peran Perguruan Tinggi dan Dunia Usaha Dalam Pemulihan Pasca Bencana Lombok (pp. 90-97). Tangerang: Universitas Multimedia Nusantara.

Republik Indonesia. Undang-Undang Republik Indonesia Nomor 32 Tahun 2004 tentang Pemerintahan Daerah (2004). Indonesia.

Richards, G., \& Raymod, C. (2000). Creative Tourism. ATLAS News, 23, 16-20. 